\title{
The impact of irrigation return flow on aspects of the water quality of the Upper Gamtoos Estuary, South Africa
}

\author{
Meryl W Pearce ${ }^{1 *}$ and Eckart H Schumann ${ }^{2}$ \\ 1 School of Geography, Population and Environmental Management, Flinders University, GPO Box 2100, Adelaide, 5001, \\ South Australia, Australia \\ 2 Department of Geology, University of Port Elizabeth, PO Box 1600, Port Elizabeth, 6000, South Africa
}

\begin{abstract}
Groundwater quality in the Loerie Flats, and subsurface irrigation return flow to the upper Gamtoos estuary was monitored from November 1992 to April 1994. The nutrient loading of groundwater was highly variable both spatially and temporally, with elevated nitrate-N levels reaching $163 \mathrm{mg} \cdot \ell^{-1}$. The elevated nutrient concentrations in the groundwater were directly related to the timing of land-surface application of fertilisers. The nutrient loading to the estuary, via subsurface irrigation return flow was calculated using Darcy's equation together with the mean concentration of nutrients found in groundwater in the Loerie Flats area. Results indicate that an average of $0.52 \mathrm{t}$ nitrate- $\mathrm{N}, 0.02 \mathrm{t}$ nitrite- $\mathrm{N}$ and $0.10 \mathrm{t}$ of total phosphorus enter the Gamtoos estuary from the $5.5 \mathrm{~km}^{2}$ Loerie Flats area on an annual basis. Such nutrient loads emanate from less than $20 \%$ of the total agricultural area bordering the estuary. Despite the elevated nutrient input to the estuary via groundwater discharge, the nutrient content of the estuary was generally low, but at times elevated concentrations of nutrients were recorded in the upper estuary. It was found that estuarine mixing processes and dilution, with adequate flushing have prevented the periods of low quality water from persisting in the Gamtoos estuary.
\end{abstract}

\section{Introduction}

Intensive agriculture has long been identified as a cause of nutrient loading of shallow groundwater (Konikow and Person, 1985; Hallberg, 1986; Sabol et al., 1987; Schmidt and Sherman, 1987). To determine the impact of irrigation return flow on receiving aquatic environments (Reay et al., 1992; Nuttle and Harvey, 1995), the volume and chemical characteristics of groundwater throughflow need to be assessed (Bokuniewicz, 1980; Johannes, 1980; Capone and Bautista, 1985; Millham and Howes, 1994). Furthermore, to identify the impact which irrigation return flow has on an estuary, it is necessary to assess the physical properties, mixing characteristics and residence times in the estuary (Birch, 1982; Kunishi, 1988; Baker and Horton, 1990).

This study has factors in common with that of Staver et al., (1996) who investigated the spatial and temporal patterns of nutrient inputs into the Choptank River estuary, USA. Like the Gamtoos estuary (South Africa), the Choptank estuary is wellmixed and shallow (less than $3 \mathrm{~m}$ deep), with land-use that is predominantly agricultural. Compared to most systems analysed elsewhere in the world, the input of freshwater into South African estuaries is very limited, and has been further reduced by the building of dams in many river catchment areas (MacKay, 1993; Jerling and Wooldridge, 1994). Where the natural flow of aquatic environments is limited, anthropogenic influences will be exacerbated, and may influence the functioning of the receiving estuary. The National Water Act (Act 36 of 1998), however, now recognises the environment as an official user of water and states that the long-term sustainability of aquatic ecosystems cannot be compromised (South African Government Gazette, 1998). The freshwater requirements of each estuary will need to be determined (a fairly complex task) so that the functioning of the ecosystems is

\footnotetext{
* To whom all correspondence should be addressed.

政 + 6188201 2327; fax: + 61882013521 ; e-mail: Meryl.Pearce@flinders.edu.au

Received 7 September 2000; accepted in revised form 22 March 2001.
}

not adversely affected, whether it be caused by an upstream impoundment or the input of contaminants from agricultural or other land use.

This paper examines the nutrient loading of groundwater in the Loerie Flats (Fig. 1), and the subsurface irrigation return flow to the upper Gamtoos estuary from the Loerie Flats. The paper also outlines the resultant effect of this input on the water quality of the Gamtoos estuary.

\section{Methods}

The location of the study site - the Loerie Flats is shown in Fig. 1, a $5.5 \mathrm{~km}^{2}$ area west of the Loerie River. The Loerie Flats is a narrow alluvial flood plain bordering the Gamtoos estuary and the Loerie River, a minor tributary. Evaporation in this region exceeds the annual average rainfall of $\sim 400 \mathrm{~mm}$ (Schulze, 1986). The presence of the Kouga Dam on the Gamtoos River has reduced the natural freshwater flow downstream in the river to less than $1 \mathrm{~m}^{3} \cdot \mathrm{s}^{-1}$. Landuse in the Loerie Flats is intensive vegetable cultivation requiring irrigation (using surface water from the Kouga Dam) and supplemental application of fertilisers and pesticides to crops to ensure sustained yields.

To examine groundwater, sixteen shallow (depth: $4.30 \mathrm{~m}$ to 5.73 $\mathrm{m})$ boreholes were installed in 4 groups as shown in Fig. 1. The variable underlying alluvial material (Zhang, 1995) necessitated the close positioning of the holes relative to one another. Soil is predominantly clay with thin lenses of sandy clay and sandy clay loam. Rest water levels (RWLs) and groundwater samples were taken monthly from November 1992 to February 1994, with limited monitoring of RWLs in five of the boreholes extended to June 1994.

The Gamtoos estuary was also monitored at 10 stations from the upper tidal limit to the estuary mouth, to determine nutrient content and depth profiles of electrical conductivity (EC), salinity and temperature. The locations of the upper tidal limit near station 1, stations 2 to 6 (bordering the Loerie Flats) and stations 7 to 9 


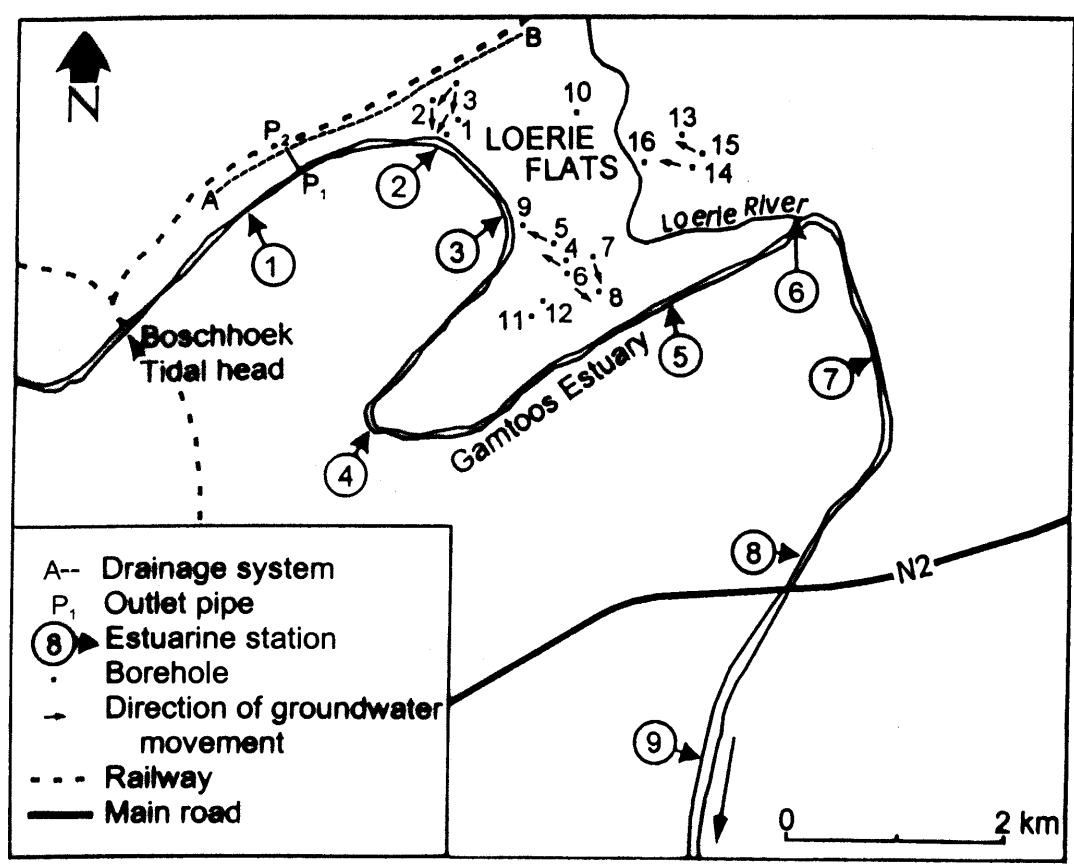

Figure 1

Map of the Loerie Flats, upper Gamtoos estuary, Loerie

River, boreholes and general direction of groundwater movement. (downstream of the confluence with the Loerie River) are shown in Fig. 1. Estuarine measurements occurred in conjunction with the borehole measurements. Samples were taken at the estimated centre of flow at low tide at both spring and neap tides. During the 16-month study period, an additional four intensive measurement periods (ranging from 6 to 18 consecutive days), entailed twice daily determinations of RWLs and physical parameters at most estuarine stations.

Aquifer recovery tests (similar to that described by Oosterbaan and Nijland, 1994) were performed on the boreholes. Hydraulic conductivity (K) was determined by applying the Ernst equation (Oosterbaan and Nijland, 1994) to the data obtained from the aquifer recovery tests. The Ernst equation Eq. 1 is given as:

$$
K=C \frac{H_{0}-H_{t}}{t}
$$

where:

$\mathrm{K}=$ hydraulic conductivity $\left(\mathrm{m} \cdot \mathrm{s}^{-1}\right)$

$\mathrm{C}=\mathrm{a}$ factor as defined in Eq. (2) below

$\mathrm{t}=$ time elapsed since the first measurement of the rising water level in the borehole (s)

$\mathrm{H}_{\mathrm{t}}=$ depth of the water level in the hole below a reference level at time $\mathrm{t}(\mathrm{m})$

$\mathrm{H}_{0}=\mathrm{H}_{\mathrm{t}}$ when $\mathrm{t}=0$

The $\mathrm{C}$ factor depends on the depth to an impermeable layer below the bottom of the hole (D), and the average depth of the water level in the hole below the water table (h') as given in Eq. 2:

$$
C=\frac{4000 \frac{r}{h^{\prime}}}{\left(20+\frac{D_{2}}{r}\right)\left(2-\frac{h^{\prime}}{D_{2}}\right)}
$$
where:

$D_{2}=$ depth of the bottom of the hole below the water table $(\mathrm{cm})$, with the condition that $20<\mathrm{D}_{2}<200$

$\mathrm{r}=$ radius of the hole $(\mathrm{cm}): 3<\mathrm{r}<7$

$h^{\prime}=$ average depth of the water level in the hole below the water table (cm), with the condition: h' $>D_{2} / 5$
In the application of Eq. 2 to the Gamtoos borehole data, D was taken to be greater than $\mathrm{D}_{2}$ (if $\mathrm{D}=0$, then a different equation for determining $\mathrm{C}$ is used).

An estimate of groundwater discharge to the estuary from the Loerie Flats was obtained using Darcy's equation (Eq. 3).

$$
Q=K A \frac{\Delta h}{L}
$$

where:

$\mathrm{Q}=$ rate of groundwater flow $\left(\mathrm{m}^{3} \cdot \mathrm{s}^{-1}\right)$

$\underline{\Delta}=$ hydraulic gradient

$\frac{\Delta \mathrm{L}}{\mathrm{L}}$

$\mathrm{A}=$ cross-sectional area $\left(\mathrm{m}^{2}\right)$

$\mathrm{K}=$ hydraulic conductivity $\left(\mathrm{m} \cdot \mathrm{s}^{-1}\right)$, obtained from Eq. 1 and Eq. 2.

The cross-sectional area $\left(30800 \mathrm{~m}^{2}\right)$ applied to Darcy's equation was calculated from the depth of the water table a.m.s.l. and the circumference of the study area bordering the estuary, from station 2 to the Loerie River $(7700 \mathrm{~m})$. The hydraulic gradient and the direction of groundwater movement were determined according to the RWLs relative to the estuary water level at the time of measurement.

This paper focuses on the nutrient content of the estuarine and groundwater samples. All water samples were analysed using standard methods (Standard Methods, 1989), nitrate $\left(\mathrm{NO}_{3}\right)$ as $\mathrm{N}$ was determined using the sodium salicylate method, whilst nitrite $\left(\mathrm{NO}_{2}\right)$ as $\mathrm{N}$ and total dissolved phosphorus (total $\mathrm{P}$ ) were determined by colorimetric development.

\section{Results and discussion}

\section{Groundwater quality}

Table 1 provides the mean values, range and standard deviations of electrical conductivity (EC) and nutrient concentrations in the 16 boreholes. No seasonal trends in groundwater quality were observed. Rather, short-term variations particularly regarding the nutrient content of groundwater occurred, and it is these results that are presented in this paper. This nutrient loading was directly related 


\begin{tabular}{|c|c|c|c|c|c|c|c|c|c|c|c|c|}
\hline \multirow{3}{*}{$\mathrm{Bh}$} & \multicolumn{12}{|c|}{$\begin{array}{l}\text { TABLE } 1 \\
\text { Mean, range and standard deviation of EC and nutrients in the } 16 \text { boreholes }\end{array}$} \\
\hline & \multicolumn{3}{|c|}{$\begin{array}{c}\mathrm{EC} \\
\mathrm{mS} \cdot \mathrm{m}^{-1}\end{array}$} & \multicolumn{3}{|c|}{$\begin{array}{l}\text { Nitrate-N } \\
\mathbf{m g} \cdot \ell^{-1}\end{array}$} & \multicolumn{3}{|c|}{$\begin{array}{c}\text { Nitrite-N } \\
\mathbf{m g} \cdot \ell^{-1}\end{array}$} & \multicolumn{3}{|c|}{$\begin{array}{l}\text { Total phosphorus } \\
\mathrm{mg} \cdot \ell^{-1}\end{array}$} \\
\hline & Mean & Range & Std dev & Mean & Range & Std dev & Mean & Range & Std dev & Mean & Range & Std dev \\
\hline 1 & 176 & 117 & 32 & 6.54 & 25.90 & 8.03 & 0.79 & 2.23 & 0.76 & 0.98 & 2.79 & 0.71 \\
\hline 2 & 264 & 226 & 51 & 27.08 & 162.93 & 45.21 & 0.38 & 1.25 & 0.38 & 1.35 & 1.98 & 0.54 \\
\hline 3 & 285 & 139 & 39 & 23.95 & 99.36 & 29.04 & 0.89 & 6.10 & 1.63 & 2.35 & 3.65 & 0.86 \\
\hline 4 & 998 & 569 & 182 & 0.21 & 1.56 & 0.41 & 0.02 & 0.11 & 0.03 & 1.31 & 3.09 & 0.91 \\
\hline 5 & 786 & 384 & 121 & 0.12 & 0.21 & 0.06 & 0.02 & 0.05 & 0.01 & 0.27 & 0.54 & 0.17 \\
\hline 6 & 698 & 632 & 160 & 0.16 & 0.65 & 0.17 & 0.01 & 0.03 & 0.01 & 0.55 & 0.76 & 0.17 \\
\hline 7 & 1712 & 1099 & 322 & 0.15 & 0.28 & 0.10 & 0.02 & 0.05 & 0.01 & 0.35 & 2.64 & 0.67 \\
\hline 8 & 3820 & 2730 & 734 & 0.29 & 2.70 & 0.72 & 0.23 & 0.76 & 0.29 & 0.80 & 3.84 & 0.95 \\
\hline 9 & 733 & 431 & 140 & 0.10 & 0.06 & 0.01 & 0.19 & 1.10 & 0.33 & 0.40 & 0.69 & 0.21 \\
\hline 10 & 3559 & 1830 & 644 & 0.10 & 0.05 & 0.01 & 0.03 & 0.18 & 0.05 & 0.53 & 2.45 & 0.71 \\
\hline $11 *$ & 1751 & - & - & 0.10 & - & - & $<0.01$ & - & - & 0.10 & - & - \\
\hline $12 *$ & 1572 & - & - & - & - & - & $<0.01$ & - & - & 0.30 & - & - \\
\hline $13 *$ & 4140 & - & - & 0.10 & - & - & $<0.01$ & - & - & 2.88 & - & - \\
\hline 14 & 5745 & 2361 & 970 & 0.10 & 0.00 & 0.00 & 0.01 & 0.04 & 0.01 & 2.49 & 3.84 & 1.52 \\
\hline 15 & 5560 & 2080 & 771 & 0.12 & 0.08 & 0.03 & $<0.01$ & 0.03 & 0.01 & 1.82 & 2.55 & 1.14 \\
\hline 16 & 449 & 448 & 173 & 0.34 & 1.38 & 0.47 & 0.05 & 0.20 & 0.06 & 0.16 & 0.23 & 0.09 \\
\hline
\end{tabular}

to the timing of land-surface application of fertilisers. Elevated nitrate-N values were recorded from May to July 1993 in boreholes $1\left(26.00 \mathrm{mg} \cdot \ell^{-1}\right), 2\left(163.00 \mathrm{mg} \cdot \ell^{-1}\right)$, and $3\left(99.50 \mathrm{mg} \cdot \ell^{-1}\right)$. Likewise, in the same boreholes nitrite-N was high from April to June 1993 with values ranging from 0.30 to $2.24 \mathrm{mg} \cdot \ell^{-1}$. Elevated nitrite-N values were also recorded at boreholes $8\left(0.76 \mathrm{mg} \cdot \ell^{-1}\right)$ and $9(1.10$ $\left.\mathrm{mg} \cdot \ell^{-1}\right)$ in April 1993 and December 1992 respectively.

Whilst the total loading of nitrogen (fertiliser applications) has been found by some researchers to be the main factor influencing the quantity of nitrate available for leaching (Schmidt and Sherman, 1987; Ritter et al., 1990), conditions which most favour the leaching of nitrate from soil are frequent changes in crop type, interspersed with lying fallow with crop residues left in the fields (Tredoux, 1993), as occurs throughout the Loerie Flats. Nitrate loading of groundwater may, however, be reduced by the processes of volatilisation and denitrification within the sediments prior to entering the estuary (Slater and Capone, 1987; Burt and Haycock, 1991).

The total phosphorus content of groundwater was routinely high at two areal clusters of boreholes (boreholes 1 to 3 and boreholes 13 to 15). In the remainder of the boreholes, the mean total phosphorus levels were generally below $1 \mathrm{mg} \cdot \ell^{-1}$ with the exception of borehole $10\left(2.46 \mathrm{mg} \cdot \ell^{-1}\right.$ was recorded in January 1993), and boreholes 7 and 8 in April 1993 (2.73 mg. $\ell^{-1}$ and 3.80 $\mathrm{mg} \cdot \ell^{-1}$ respectively).

Seepages were frequently observed along the banks of the Gamtoos estuary, particularly between stations 2 and 4 . Whilst they were mostly observed in this area, the presence of thick bank vegetation may have obscured the observation of seepages in other areas. One such seepage, approximately $70 \mathrm{~m}$ from borehole 9 , was sampled on one occasion. The seepage exhibited some similarity to groundwater in the vicinity at the time of sampling (EC 595 $\mathrm{mS} \cdot \mathrm{m}^{-1}, 9.14 \mathrm{mg} \cdot \ell^{-1}$ nitrate- $\mathrm{N}, 0.26 \mathrm{mg} \cdot \ell^{-1}$ nitrite- $\mathrm{N}, 0.79 \mathrm{mg} \cdot \ell^{-1}$ total phosphorus). Groundwater flow paths (drawn as small arrows in Fig. 1) indicate that groundwater had moved from an area of recharge in the vicinity of boreholes 4 and 5 towards the estuary near borehole 9, which would account for the similarities in hydrochemistry.

\section{Groundwater discharge}

Groundwater movement generally occurred outward from a number of localised recharge zones towards the estuary. Slight variations in the areas of recharge occurred; for example the elevated water table shifted from the vicinity of boreholes 4 and 6 to the vicinity of borehole 5 in December 1992, January and November 1993 and February and April 1994. Minor fluctuations in the water table level occurred in response to light rainfall, with minor localised changes occurring in response to irrigation. Groundwater direction of flow in the vicinity of boreholes 7 and 8 differed from that of the other boreholes at that grouping, moving southward towards the estuary.

The subsurface irrigation return flow from the study area to the estuary was calculated using Darcy's equation, to be on average $276 \mathrm{~m}^{3}$ per day (based on 1994 data). Compounding any estimation of groundwater discharge is that the rate and direction of discharge will change in response to fluctuating groundwater levels and hydraulic gradient (cf. Staver and Brinsfield, 1996). Groundwater in the Loerie Flats is not only influenced by seasonal fluctuations in water table related to trends in rainfall recharge, but bordering an estuarine system, also to tidal fluctuations.

The aquifer recovery tests were conducted in 1994, a year characterised by average rainfall conditions $(496.3 \mathrm{~mm}$, which is close to the 20-year running mean rainfall in the Gamtoos region of $422.5 \mathrm{~mm}$ per annum (rainfall records, Weather Bureau, 1994)). It is unfortunate that aquifer recovery tests were not conducted in 


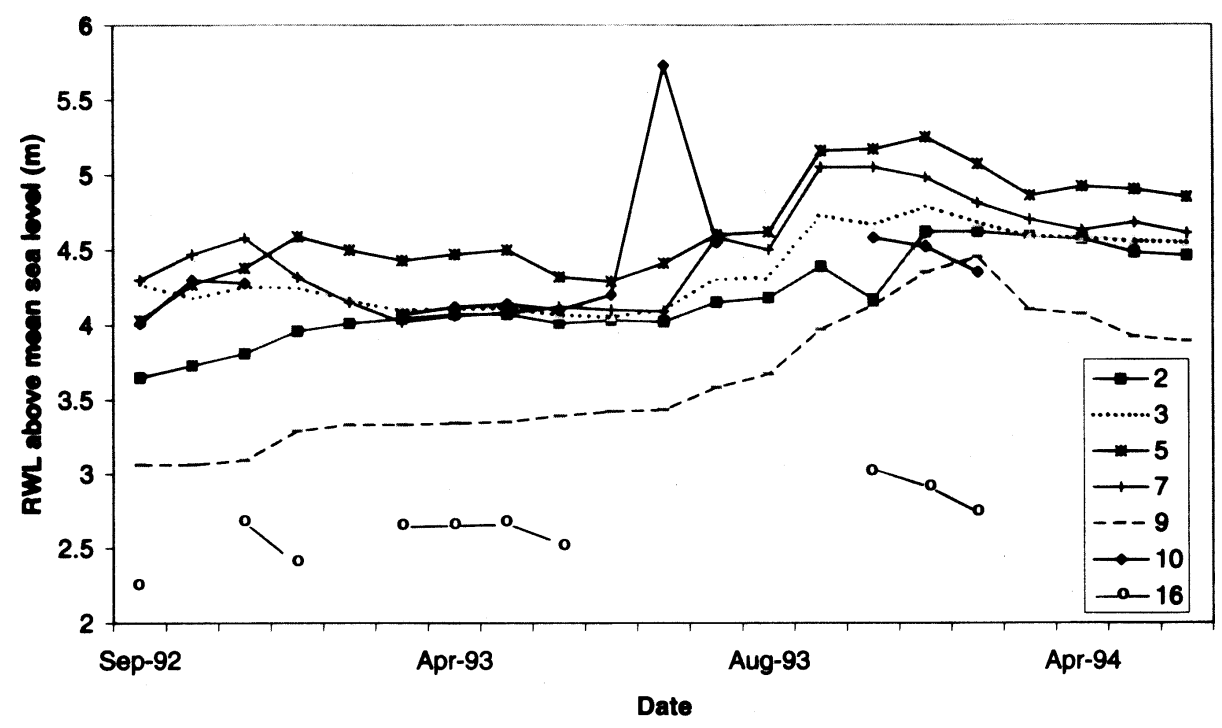

Figure 2

Rest water levels relative to mean sea level in a number of boreholes from each areal cluster of boreholes in the Loerie Flats area from the time of installation (September 1992) to June 1994

earlier years of the study as 1992 was a markedly dry year (314.3 $\mathrm{mm}$ ) with the situation exacerbated as farmers were on reduced irrigation quotas. During the dry year (1992) a lower discharge would be expected because of the lower water table which would imply a lesser hydraulic gradient. Conversely, during wetter years (such as in 1993 when above average rainfall $(642.1 \mathrm{~mm})$ occurred) a greater discharge would be expected as a result of a steeper hydraulic gradient to the estuary, created by an elevated water table in the adjacent flood plain. Despite the differences in rainfall and irrigation there was little difference (on average less than $0.2 \mathrm{~m}$ ) in water table levels in late 1992 (at the commencement of the project) compared with that of the first 5 months of 1993 as shown in Fig. 2 . The main change in the water table trend, however, came within 4 days of the heavy June 1993 rainfall, when the water table in the Loerie Flats rose steadily and ,thereafter, was about 0.5 to $1 \mathrm{~m}$ higher than that prior to June 1993. A slight decline in the water table (of around $0.1 \mathrm{~m}$ ) occurred during late summer of 1993 and early 1994, with the water table showing minimal further change up to June 1994. As the aquifer recovery tests were conducted in the final year of the project inter-annual comparisons of groundwater discharge are not available. Nonetheless, the results presented are the only data available for the Loerie Flats and, whilst not statistically rigorous, provide an indication of diffuse groundwater inputs into the Gamtoos estuary.

In coastal and estuarine regions, groundwater levels may fluctuate in response to tidal fluctuations as a pressure wave propagates inland through the adjacent aquifer (Serfes, 1991). The characteristics of the pressure waves are a function of the tidal period, tidal amplitude and aquifer transmissivity. Fluctuations in the RWLs in the Loerie Flats, however, showed no correlation with tidal fluctuations in the Gamtoos estuary. Furthermore, the low aquifer transmissivity throughout the flood plain (mean $0.47 \mathrm{~m}$ per day, Pearce and Schumann, 1997) would hinder the transmission of pressure waves through the aquifer, with pressure effects further reduced by the shallow unconfined nature of the aquifer.

Tidal fluctuations although found to have no influence on groundwater level fluctuations in the Loerie Flats, will affect the hydraulic gradient. With an increase in the hydraulic gradient there will be a proportional increase in groundwater discharge to the estuary. A system with large tidal fluctuations would necessitate additional calculations (for groundwater discharge) for each cycle of tidal change. In the Gamtoos estuary, however, the tidal lag time in the vicinity of estuarine station 2 was $2 \mathrm{~h} 27 \mathrm{~min}$ and at this point the tidal amplitude is attenuated, being $0.5 \mathrm{~m}$ at spring tide and 0.2 m during neap tide. The combined effects of low tidal amplitude and period, and the distance of boreholes from the estuary would also account for the absence of any tidal effect in borehole water levels. Given the low tidal amplitude and minimal fluctuations in groundwater levels, it is appropriate to base groundwater discharge calculations on the mean discharge of $276 \mathrm{~m}^{3}$ per day. Regardless of rainfall conditions, the water table was at a higher elevation than the estuary throughout the study period which would favour a continual preferential discharge of groundwater to the estuary during both high and low tide, with the minimal short-term proportional flux varying with tide.

An indication of the input of nutrients to the Gamtoos estuary, via subsurface irrigation return flow, is obtained by examining the nutrient content of groundwater abstracted from the boreholes and the subsurface discharge to the estuary. As groundwater discharge and quality (as seen in Table 1) varies throughout the area, so too, the proportion of nutrients entering the estuary via irrigation return flow will vary spatially and temporally.

Nitrate-N levels in groundwater in the Loerie Flats ranged from $0.10 \mathrm{mg} \cdot \ell^{-1}$ to $163.00 \mathrm{mg} \mathrm{mg} \cdot \ell^{-1}$, with a mean of $5.16 \mathrm{mg} \mathrm{mg} \cdot \ell^{-1}$ (standard deviation 18.34). Applying the mean nitrate-N concentration of $5.16 \mathrm{mg} \mathrm{mg} \cdot \ell^{-1}$, and given the average groundwater discharge of $276 \mathrm{~m}^{3}$ per day, a total of 0.52 tons of nitrate-N will enter the estuary on an annual basis. While the average annual nitrate-N input into the estuary is 0.52 tons, the loading could be as high as 16.4 tons (if the maximum nitrate concentration of 163.00 $\mathrm{mg} \cdot \ell^{-1}$ is used in the calculation). Nitrite- $\mathrm{N}$ and total phosphorus loads were calculated in a similar manner. Calculations based on the mean nitrite- $\mathrm{N}$ for the area $\left(0.22 \mathrm{mg} \cdot \ell^{-1}\right.$; standard deviation 0.62$)$ yields an input of 0.02 tons of nitrite-N into the estuary on an annual basis; when based on the maximum nitrite-N recorded $(2.24$ $\mathrm{mg} \cdot \ell^{-1}$ ) would yield an input of 0.61 tons per annum. The mean and maximum total phosphorus content of groundwater in the Loerie Flats was $0.94 \mathrm{mg} \cdot \ell^{-1}$ (standard deviation 0.98 ) and $3.97 \mathrm{mg} \cdot \ell^{-1}$ respectively, these concentrations yield an input of 0.10 and 0.40 trespectively of total phosphorus into the estuary on an annual basis. Given that the boreholes did not display elevated nutrient levels simultaneously, the nutrient inputs into the estuary will be closer to the mean values of $0.52 \mathrm{t}$ nitrate-N, $0.02 \mathrm{t}$ nitrite- $\mathrm{N}$, and 0.10 tons total phosphorus than the upper range of inputs. The average nutrient loads are, nonetheless, conservative estimates. Furthermore, they emanate from an area which comprises less than $20 \%$ of the total agricultural area bordering the estuary. Irrigation return flow along the entire expanse of the estuary including the 
west bank, as well as deeper groundwater inputs would yield a substantial diffuse source of nutrients to the estuary.

\section{Nutrient levels in the Gamtoos estuary}

Nitrogen and more particularly phosphorus are the main indicators of the nutrient status of a water body. As seen in Table 2, the nitrate- $\mathrm{N}$ levels throughout the estuary during the study period were routinely low, being equal to or below the detection sensitivity for the method of determination i.e. $0.10 \mathrm{mg} \cdot \ell^{-1}$. This level was exceeded on 3 of the sampling dates at a number of estuarine stations. These being on 15 June 1993 at station 6; on 26 August 1993 at stations 2, 5 and 6; and on 12 October at station 2. The recommended nitrite- $\mathrm{N}$ and total phosphorus limit for the protection of estuarine aquatic life is $0.06 \mathrm{mg} \cdot \ell^{-1}$ for each constituent (Dallas and Day, 1993). The recommended nitrite-N limit was exceeded at stations $3\left(0.18 \mathrm{mg} \cdot \ell^{-1}\right)$ and $4\left(0.16 \mathrm{mg} \cdot \ell^{-1}\right)$ in June 1993 and at station $2\left(0.15 \mathrm{mg} \cdot \ell^{-1}\right)$ on 6 November 1993 . Elevated nitrite$\mathrm{N}$ levels ranging from 0.07 to $0.27 \mathrm{mg} \cdot \ell^{-1}$ were also recorded between November 1993 and February 1994 at station 7 which is also bordered by agricultural lands. The recommended total phosphorus concentration was exceeded (on average) at all ten stations (Table 2). The mean total phosphorus for the ten estuarine stations was $0.20 \mathrm{mg} \cdot \ell^{-1}$ (standard deviation 0.43 ), with extreme values being recorded at station $1\left(1.02 \mathrm{mg} \cdot \ell^{-1}\right)$ and at station $5(3.81$ $\mathrm{mg} \cdot \ell^{-1}$ ) both on 15 May 1993.

This study did not examine the irrigation return flow to the Gamtoos River upstream of the tidal head at Boschhoek (Fig. 1). However, the inflow of nutrients to the estuary from the river upstream (as recorded at station 1 near the tidal limit of the estuary), was generally low, with 2 exceptions. In February 1994 a nitrite-N concentration of $0.07 \mathrm{mg} \cdot \ell^{-1}$ was recorded and the previously mentioned total phosphorus concentration of $1.02 \mathrm{mg} \cdot \ell^{-1}$ (in May 1993).

\section{The fate of the nutrients entering the estuary}

The fate of the contaminants entering the Gamtoos estuary is determined by estuarine processes: physical properties, mixing characteristics and residence times in the estuary, and also by the freshwater input to the estuary. It is important that nutrient inputs to the estuary do not accumulate, and the extent of estuarine circulation will determine the residence time of such nutrients, amongst other factors. A detailed description of the Gamtoos estuarine hydrodynamics is given in Schumann and Pearce (1997) and is not repeated here. A brief synopsis of findings relevant to this study are included in the discussion to follow. The Gamtoos, like many other estuaries in the semi-arid regions of South Africa (MacKay and Schumann, 1990; Largier and Slinger, 1991;
TABLE 2

iation of nutrients in the Gamtoos estuary

\begin{tabular}{|c|c|c|c|c|c|}
\multicolumn{3}{|c|}{$\begin{array}{c}\text { Nitrite-N } \\
\text { mg. } \ell^{-1}\end{array}$} & \multicolumn{3}{c|}{$\begin{array}{c}\text { Total phosphorus } \\
\text { mg } \ell^{-1}\end{array}$} \\
Mean & Range & Std dev & Mean & Range & Std dev \\
0.01 & 0.07 & 0.02 & 0.15 & 0.98 & 0.23 \\
0.02 & 0.15 & 0.04 & 0.12 & 0.21 & 0.05 \\
0.03 & 0.17 & 0.06 & 0.11 & 0.10 & 0.03 \\
0.02 & 0.26 & 0.04 & 0.15 & 0.05 & 0.03 \\
0.007 & 0.02 & 0.005 & 0.40 & 3.77 & 0.95 \\
0.009 & 0.01 & 0.005 & 0.69 & 3.16 & 1.15 \\
0.02 & 0.27 & 0.04 & 0.13 & 0.40 & 0.07 \\
0.009 & 0.01 & 0.005 & 0.10 & 0.04 & 0.02 \\
0.008 & 0.01 & 0.007 & 0.14 & 0.23 & 0.11 \\
0.01 & 0.02 & 0.007 & 0.36 & 0.40 & 0.18 \\
\hline
\end{tabular}

$$
7 \text { where } \mathrm{N}=58
$$

Schumann et al., 1997) receives a low freshwater input (estimated at less than $1 \mathrm{~m}^{3} \cdot \mathrm{s}^{-1}$ ), with tidal currents being the main factor contributing to mixing within the estuary. The Gamtoos estuary is semidiurnal, micro-tidal with neap tide amplitudes at the mouth around $0.5 \mathrm{~m}$ and spring tides at times greater than $2.0 \mathrm{~m}$ (South African Naval Hydrographer, 1998). Estuary-ocean exchanges, which are largely determined by the configuration of the estuary mouth, are important for the flushing of the estuary and removal of nutrients to the ocean. However, increasing sedimentation at the Gamtoos tidal inlet over the past number of years has resulted in tidal attenuation immediately inside the flood tidal delta to $30 \%$ of that in the adjacent ocean, and, therefore, in reduced estuary-ocean exchanges. The situation is exacerbated by the presence of shallow, aggraded sandbanks upstream of station 4 , which causes a restriction of tidal flushing in the upper estuary. During prolonged dry conditions, with decreased freshwater flow a nutrient build-up could occur in the upper estuary. Such an accumulation of nutrients could, in turn, lead to the proliferation of phytoplankton and macrophyte growth (Cole, 1973 as cited by Dallas and Day, 1993). According to Schlacher and Wooldridge (1996), of the total primary production in the Gamtoos estuary, microalgae predominate (87\%). Excessive primary production will have effects up the estuarine food chain. In retrospect, chlorophyll analyses should have been performed simultaneously with the nutrient analyses. Nonetheless, the only visible sign of any nuisance macrophytic growth in the Gamtoos estuary was the presence of Azolla filiculoides in the shaded, low-flow areas of the upper estuary. The presence of Azolla filiculoides is not necessarily indicative of high nutrient levels, as it can assimilate atmospheric nitrogen through its symbiotic relationship with Anabaena azollae. It does, however, have a high phosphate requirement (Bieleski and Lauchli, 1992).

Whilst the middle and lower reaches of the estuary are mostly well-mixed during spring high tides (by the input of seawater through the tidal inlet), in the event of rainfall, a freshwater inflow to the upper estuary in excess of $1 \mathrm{~m}^{3} \cdot \mathrm{s}^{-1}$ is sufficient to flush out the upper reaches of the estuary. Nutrients are removed downstream of the shallow aggraded section to an area where tidal mixing and dilution can occur, with subsequent flushing of the estuary during low tide. 


\section{Conclusion}

Both point source and diffuse inputs have resulted in the periodically elevated nutrient levels in the Gamtoos estuary. Pearce and Schumann (1994) discuss the point-source discharges, thus the focus of the present paper is on the diffuse inputs (subsurface irrigation return flow) into the estuary. Despite the occasional high nitrite-N and total phosphorus levels at certain sites (particularly in the upper estuary), the nutrient levels in the estuary are generally low. This may be partly attributed to sedimentation of phosphorus and nitrogen and rapid denitrification and volatilisation of nitrogen. Furthermore, the utilisation of nutrients during primary production may also result in low nutrient levels, but this did not form part of the investigation. The presence of nutrients in the Gamtoos estuary did not persist as there was adequate dilution, with increased mixing in the middle and lower sections of the estuary, and subsequent flushing of the estuary during low tide.

\section{Acknowledgments}

The Water Research Commission is acknowledged for funding the research. The authors would like to thank Jonathan Churchill, Zanne and Elsje, the students who assisted with the field measurements, and the Gamtoos farmers for allowing them access to their property.

\section{References}

BAKER WC and HORTON T (1990) Runoff and the Chesapeake Bay. EPA J. 16 (6) 13-16.

BIELESKI RL and LAUCHLI A (1992) Phosphate uptake, efflux and deficiency in the water fern Azolla. Plant, Cell Environ. 15 665-673.

BIRCH PB (1982) Phosphorus export from coastal plain drainage into the Peel-Harvey estuarine system of Western Australia. Aust. J. Mar. Freshwater Res. 33 (1) 23-32.

BOKUNIEWICZ H (1980) Groundwater seepage into Great South Bay, New York. Estuarine Coastal Mar. Sci. 10 437-444.

BURT T and HAYCOCK N (1991) Farming and nitrate pollution. Geogr. 60-63.

CAPONE DG and BAUTISTA MF (1985) A groundwater source of nitrate in nearshore sediments. Nature 313 214-216.

DALLAS HF and DAY JA (1993) The Effect of Water Quality Variables on Riverine Ecosystems: A Review. WRC Report No TT 61/93.

HALLBERG GR (1986) From hoes to herbicides, agriculture and groundwater quality. J. Soil Water Conserv. (Nov-Dec) 357-364.

JERLING HL and WOOLDRIDGE TH (1994) The mesozooplankton of a freshwater-starved estuary. In: Dyer KR and Orth RJ (eds.) Changes in Fluxes in Estuaries. Olsen and Olsen, Fredensborg, Denmark, 301306.

JOHANNES RE (1980) The ecological significance of the submarine discharge of groundwater. Mar. Ecol. Prog. Ser. 3 365-373.

KONIKOW LF and PERSON M (1985) Assessment of long-term salinity changes in an irrigated stream - aquifer system. Water Resour. Res. 21 (11) 1611-1624.

KUNISHI HM (1988) Sources of nitrogen and phosphorus in an estuary of the Chesapeake Bay. J. Environ. Qual. 17 (2) 185-188.

LARGIER JL and SLINGER JH (1991) Circulation in highly stratified Southern African estuaries. S. Afr. J. Aquat. Sci. 17 103-115.

MACKAY HM and SCHUMANN EH (1990) Mixing and circulation in the Sundays River estuary, South Africa. Estuarine Coastal Shelf Sci. 31 203-216.
MACKAY HM (1993) The Impact of Urban Runoff on the Water Quality of the Swartkops Estuary: Implications for Water Quality Management. WRC Report No KV 45/93.

MILLHAM NP and HOWES BL (1994) Nutrient balance of a shallow coastal embayment: I. Patterns of groundwater discharge. Mar. Ecol. Prog. Ser. 112 155-167.

NUTTLE WK and HARVEY JW (1995) Fluxes of water and solute in a coastal wetland sediment. 1. The contribution of regional groundwater discharge. J. Hydrol. 164 (1) 89-107.

OOSTERBAAN RJ and NIJLAND HJ (1994) Determining the saturated hydraulic conductivity. In: Ritzema HP (ed.) Drainage Principles and Applications ( $2^{\text {nd }}$ edn.). ILRI Publication 16, Netherlands. 435-476.

PEARCEMW and SCHUMANNEH(1994) Water quality of an agricultural drainage system in the Gamtoos flood plain. In: Proc. of the 50 Years of Water Eng. in S. Afr.: A Tribute to Des Midgley Conf., Univ. of the Witwatersrand, Johannesburg. 14-15 July. 563-571.

PEARCE MW and SCHUMANN EH (1997) The Effect of Land Use on Gamtoos Estuary Water Quality. WRC Report No 503/1/97.

REAY WG, GALLAGHER DL and SIMMONS GM (1992) Groundwater discharge and its impact on surface water quality in a Chesapeake Bay inlet. Water Resour. Bull. 28 (6) 1121-1134.

RITTER WF, CHIRNSIDE AEM and SCARBOROUGH RW (1990) Soil nitrate profiles under irrigation on coastal plain soils. J. Irrig. Drain. Div. ASCE 116 (6) 738-751.

SABOL GV, BOUWER H and WIERENGA PJ (1987) Irrigation effects in Arizona. J. Irrig. Drain. Div. ASCE 113 (1) 30-48.

SCHLACHER TA and WOOLDRIDGE TH (1996) Origin and trophic importance of detritus - Evidence from stable isotopes in the benthos of a small, temperate estuary. Oecologia 106 382-388.

SCHMIDT KD and SHERMAN I (1987) Effect of irrigation on groundwater quality in California. J. Irrig. Drain. Div. ASCE 113 (1) 16-29.

SCHULZE BR (1986) Climate of South Africa (6 $6^{\text {th }}$ edn., Part 8). General Survey, Weather Bureau, Dept. of Transport, Government Printer, Pretoria.

SCHUMANN EH, LARGIER JL and SLINGER JH (1997) Estuarine hydrodynamics. In: Allanson B and Baird D (eds.) Estuaries of South Africa. Cambridge Univ. Press, Cambridge.

SCHUMANN EH and PEARCE MW (1997) Freshwater inflow and estuarine variability in the Gamtoos estuary, South Africa. Estuaries 20 (1) 124-133.

SERFES ME (1991) Determining the mean hydraulic gradient of groundwater affected by tidal fluctuations. Ground Water 29 (4) 549-555.

SLATER JM and CAPONE DG (1987) Denitrification in aquifer soil and nearshore marine sediments influenced by groundwater nitrate. Appl. Environ. Microbiol. 52 1292-1297.

SOUTH AFRICAN GOVERNMENT GAZETTE (1998) The National Water Act No. 36 of 1998. 19980826. Government Printer, Pretoria.

SOUTH AFRICAN NAVAL HYDROGRAPHER (1998) South African Tide Tables. Tokai, Cape Town.

STANDARD METHODS (1989) Standard Methods for the Examination of Water and Wastewater (18 $8^{\text {th }}$ edn.), American Public Health Association/American Water Works Association/Water Environment Federation, Washington DC, USA.

STAVER LW, STAVER KW and STEVENSON JC (1996) Nutrient inputs to the Choptank River Estuary: Implications for watershed management. Estuaries 19 (2B) 342-358.

STAVER KW and BRINSFIELD RB (1996) Seepage of groundwater nitrate from a riparian agrosystem into the Wye River estuary. Estuaries 19 (2B) 359-370.

TREDOUX G (1993) A Preliminary Investigation of the Nitrate Content of Groundwater and the Limitation of the Nitrate Input. WRC Report No 368/1/93.

ZHANG P (1995) Evolution of the Gamtoos River Flood Plain. M.Sc. Thesis, Dept. of Geol., Univ. of Port Elizabeth. 